\title{
Significance of the clay mineral distribution in the fluvial sediments of the Neogene Himalayan Foreland Basin (central Nepal)
}

\author{
Pascale Huyghe $^{1^{*}}$, Romain Guilbaud ${ }^{1}$, Matthias Bernet ${ }^{1}$ and Ananta Prasad Gajurel ${ }^{2}$ \\ 1 LGCA, Maison des Géosciences, Université de Grenoble, BP53, 38041 Grenoble, FRANCE \\ 2 Department of Geology, Tribhuvan University, Kathmandu, NEPAL \\ * For correspondence, email: huyghe@uif-grenoble.fr
}

Sandstones and mudstones of Siwalik fluvial formations (Surai Khola and the Tinau Khola sections, western-central Nepal) and sand and clay of the modern Ganga drainage system were analysed for clay mineralogy. The clayey assemblage is composed of illite, chlorite, smectite and kaolinite. Illite and chlorite mineral are mainly of detrital origin, provided by Lower Himalayan and High Himalayan sources. From depth of about $2500 \mathrm{~m}$, diagenetic processes have affected the original clay signature and illitization of smectites occurs from $2500 \mathrm{~m}$ depth $\left(\sim 70-95^{\circ} \mathrm{C}\right)$. Dickitisation of kaolinite occurs from $3000 \mathrm{~m}$ depth $\left(\sim 110^{\circ} \mathrm{C}\right)$. Illite particles therefore consist of a mixture of inherited illites and illitized smectites, as suggested by illite crystallinity. Kaolinites and smectites have essentially authigenic forms although some detrital particles may also be observed. They mainly occur within the porosity and as coating of detrital particles.
Despite essentially felsic rock sources and dominant physical erosion processes in the Himalayan belt, smectites are abundant in the $<7 \mathrm{Ma}$ Siwalik deposits. Their great occurrence can not be explained by source changes and they seem to be essentially of authigenic origin. Detailed analysis of an individual fluvial Siwalik sequence, and comparison with the clay mineralogy of the modern drainage system suggest that smectites preferentially form in plain and low topographic areas preserved from erosion such as intra-mountainous valleys. Downward percolating cations released during soil formation concentrate (and may evaporate) and may precipitate smectites clay minerals along their pathways during eodiagenesis. The increasing seasonality and aridity linked to intensification of monsoon from $8 \mathrm{Ma}$ has enhanced clay authigenesis in these areas. 